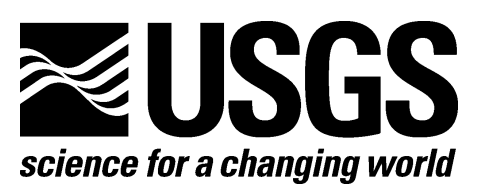

\title{
Geologic Field Notes and Geochemical Analyses of Outcrop and Drill Core from Mesoproterozoic Rocks and Iron-Oxide Deposits and Prospects of Southeast Missouri
}

By Warren C. Day and Matthew Granitto

Open-File Report 2014-1053

U.S. Department of the Interior

U.S. Geological Survey 


\section{U.S. Department of the Interior \\ SALLY JEWELL, Secretary}

\section{U.S. Geological Survey \\ Suzette M. Kimball, Acting Director}

U.S. Geological Survey, Reston, Virginia: 2014

For more information on the USGS—-the Federal source for science about the Earth, its natural and living resources, natural hazards, and the environment-visit http://www.usgs.gov or call 1-888-ASK-USGS

For an overview of USGS information products, including maps, imagery, and publications, visit http://www.usgs.gov/pubprod

To order this and other USGS information products, visit http://store.usgs.gov

Suggested citation:

Day, W.C., and Granitto, Matthew, 2014, Geologic field notes and geochemical analyses of outcrop and drill core from Mesoproterozoic rocks and iron-oxide deposits and prospects of southeast Missouri: U.S. Geological Survey Open-File Report 2014-1053, 7 p., http://dx.doi.org/10.3133/ofr20141053.

ISSN 2331-1258 (online)

Any use of trade, product, or firm names is for descriptive purposes only and does not imply endorsement by the U.S. Government.

Although this information product, for the most part, is in the public domain, it also may contain copyrighted materials as noted in the text. Permission to reproduce copyrighted items must be secured from the copyright owner. 


\section{Contents}

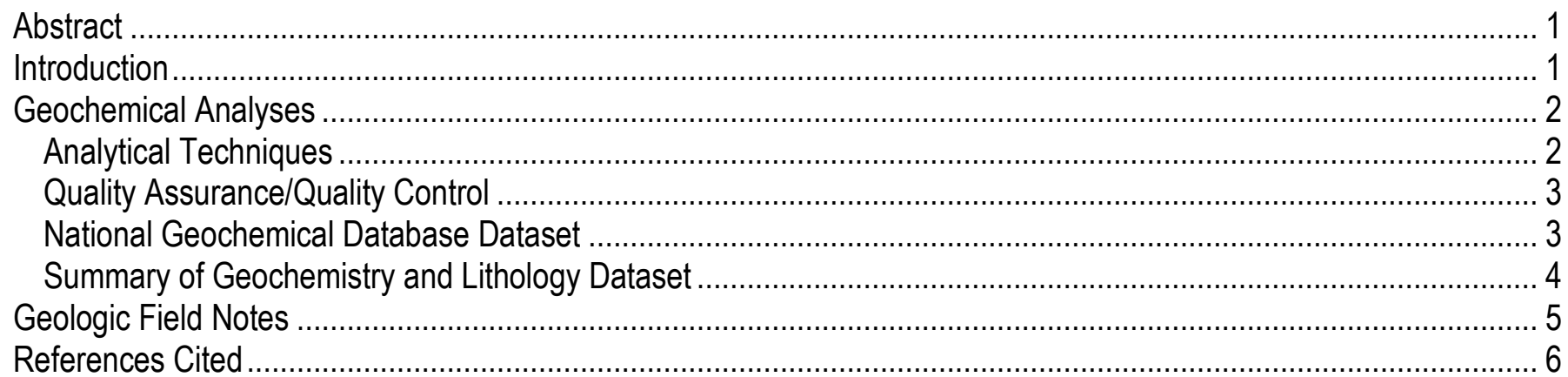

\section{Tables}

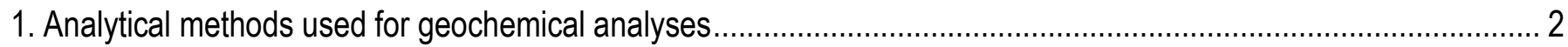

2. Chemical species and their lower limits of determination (LLD)................................................................. link

3. National Geochemical Database dataset............................................................................................... link

4. Chemical parameters ....................................................................................................................... link

5. Summary geochemistry and lithology dataset ………........................................................................... link

6. Field notes for Pea Ridge Iron Mine ................................................................................................... link

7. Field notes for surface outcrops ........................................................................................................ link 


\section{Conversion Factors}

Inch/Pound to SI

\begin{tabular}{lcl}
\hline \multicolumn{1}{c}{ Multiply } & By & \multicolumn{1}{c}{ To obtain } \\
\hline & Length & \\
\hline inch (in.) & 2.54 & centimeter (cm) \\
inch (in.) & 25.4 & millimeter (mm) \\
foot (ft) & 0.3048 & meter (m) \\
\hline
\end{tabular}

SI to Inch/Pound

\begin{tabular}{lll}
\hline Multiply & \multicolumn{1}{c}{ By } & \multicolumn{1}{c}{ To obtain } \\
\hline & Length & \\
\hline centimeter $(\mathrm{cm})$ & 0.3937 & inch (in.) \\
millimeter $(\mathrm{mm})$ & 0.03937 & inch (in.) \\
meter $(\mathrm{m})$ & 3.281 & foot (ft) \\
meter $(\mathrm{m})$ & 1.094 & yard (yd) \\
\hline
\end{tabular}




\title{
Geologic Field Notes and Geochemical Analyses of Outcrop and Drill Core from Mesoproterozoic Rocks and Iron-Oxide Deposits and Prospects of Southeast Missouri
}

\author{
By Warren C. Day and Matthew Granitto
}

\begin{abstract}
The U.S. Geological Survey, in cooperation with the Missouri Department of Natural Resources/Missouri Geological Survey, undertook a study from 1988 to 1994 on the iron-oxide deposits and their host Mesoproterozoic igneous rocks in southeastern Missouri. The project resulted in an improvement of our understanding of the geologic setting, mode of formation, and the composition of many of the known deposits and prospects and the associated rocks of the St. Francois terrane in Missouri. The goal for this earlier work was to allow the comparison of Missouri iron-oxide deposits in context with other iron oxide-copper \pm uranium (IOCG) types of mineral deposits observed globally. The raw geochemical analyses were released originally through the USGS National Geochemical Database (NGDB, http://mrdata.usgs.gov). The data presented herein offers all of the field notes, locations, rock descriptions, and geochemical analyses in a coherent package to facilitate new research efforts in IOCG deposit types. The data are provided in both Microsoft Excel (Version Office 2010) spreadsheet format (*.xlsx) and MS-DOS text formats (*.txt) for ease of use by numerous computer programs.
\end{abstract}

\section{Introduction}

This report presents the field data and geochemical analyses that supported U.S. Geological Survey (USGS) research carried out from 1988 to 1994 on the iron-oxide ( \pm rare earth element \pm copper \pm gold \pm uranium) deposits and prospects, and their host Precambrian granite-rhyolite rocks in southeastern Missouri. The effort was part of a five-year USGS project effort, funded by the Mineral Resources Program, to understand the origin and mineral resource potential of iron-oxide deposits that have similarities to other iron-oxide, copper, gold (IOCG) deposits worldwide. A general discussion of the IOCG mineral deposit type can be found in Hitzman (2000), Williams and others (2005), Groves and others (2010), and Richards and Mumin (2013) and references therein.

The USGS effort entailed detailed geologic mapping at the Pea Ridge iron oxide-apatite deposit (Seeger and others, 2001), which has notable rare earth element (REE) \pm gold-bearing breccia pipes. Currently, the Pea Ridge mine is flooded with no access to the underground workings, so the data presented herein, as well as the geologic mapping of Seeger and others (2001), preserve our understanding of this important deposit. This report also includes numerous field observations and geochemical analyses from other iron-oxide \pm copper \pm gold deposits and prospects throughout the St. Francois terrane (Boss-Bixby, Camels Hump, Kratz Spring, Bourbon, Iron Mountain, Shepherd Mountain, Cedar Hill, upper and lower Pilot Knob, Ketcherside Gap, and Cuthbertson Mountain) as 
well as the Silver Mines silver-lead-tungsten deposit, all hosted in the Mesoproterozoic St. Francois terrane of southeastern Missouri.

The field work presented in this report occurred over one- and two-week-long field sessions during 1988-1993 by W.C. Day and G.B. Sidder (USGS and formerly of the USGS, respectively). Numerous observations were made in conjunction with Dr. Cheryl M. Seeger of the Missouri Department of Natural Resources Missouri Geological Survey (MDNR/MGS) and Mark A. Marikos, Laurence M. Nuelle, and Charles Roberts, all formerly with the MDNR/MGS. These observations underpin many of the observations and conclusions presented in numerous papers and maps from the project, including Cordell and others (1993), Day and others (1989, 1991, 1992, 1993, and 2001), Nuelle and others (1989a,b, 1991a,b,c, 1992), Seeger and others (2001), and Sidder and others (1991, 1993a,b), Sidder and Day (1993). The geochemical data, compiled by Matthew Granitto, from the USGS National Geochemical Survey Database (NGDB, http://mrdata.usgs.gov/geochemistry/ngdbrock.html) provided the context for the analytical methods and levels of detection important for understanding the origin and limitations of the geochemical data. The data are provided in both Microsoft Excel (Version Office 2010) spreadsheet format (*.xlsx) and MS-DOS text formats (*.txt).

\section{Geochemical Analyses}

The chemical, geologic, and geospatial data are presented as two sets of tables that include distinct geochemical data. Tables 1 through 5 contain the exhaustive data for 318 rock samples shown in the USGS NGDB as well as the parameters critical for describing the geochemical data. Tables 6 and 7 provide summarized and interpreted geologic observations and location information for the same samples.

\section{Analytical Techniques}

Nineteen different analytical methods were employed by the laboratories of the former Branch of Geochemistry of the USGS from 1989 to 1994 to produce the geochemical data presented in this report. Table 1 provides a complete list of these methods and descriptive information for each.

Table 1. Analytical methods used for geochemical analyses.

\begin{tabular}{|c|c|c|}
\hline Abbreviation & Analytical Method Description & Digestion Method \\
\hline AA_CV & $\begin{array}{l}\text { Mercury by cold-vapor atomic absorption spectrometry (AAS) after multi-acid } \\
\text { digestion and solution. }\end{array}$ & $\mathrm{HNO}_{3}-\mathrm{Na}_{2} \mathrm{Cr}_{2} \mathrm{O}_{7}$ \\
\hline AA_GF_HBr & 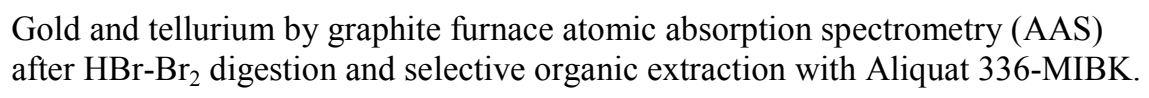 & $\mathrm{HBr}-\mathrm{Br}_{2}$ \\
\hline AES_AZ_P & $\begin{array}{l}\text { Silver, arsenic, gold, bismuth, cadmium, copper, molybdenum, lead, antimony } \\
\text { and zinc by inductively coupled plasma-atomic emission spectrometry (ICP- } \\
\text { AES) after partial digestion with } \mathrm{HCl}-\mathrm{H}_{2} \mathrm{O}_{2} \text {. }\end{array}$ & $\mathrm{HCl}-\mathrm{H}_{2} \mathrm{O}_{2}$ \\
\hline AES_HF & $\begin{array}{l}\text { Major and minor elements by inductively coupled plasma-atomic emission } \\
\text { spectrometry (ICP-AES) after digestion with } \mathrm{HF}-\mathrm{HCl}-\mathrm{HNO}_{3}-\mathrm{HClO}_{4} \text {. }\end{array}$ & $\mathrm{HF}-\mathrm{HCl}-\mathrm{HNO}_{3}-\mathrm{HClO}_{4}$ \\
\hline $\mathrm{CP}$ & Whole rock total and iron trioxide by computation. & None \\
\hline $\mathrm{DN}$ & Uranium and thorium by delayed neutron activation counting. & None \\
\hline
\end{tabular}


Table 1. Analytical methods used for geochemical analyses.-Continued

\begin{tabular}{|c|c|c|}
\hline Abbreviation & Analytical Method Description & Digestion Method \\
\hline EDX & Minor elements by energy-dispersive X-ray fluorescence (XRF) spectrometry. & None \\
\hline ES_SQ & Major and minor elements by semi-quantitative emission spectrography. & None \\
\hline FA_MS & $\begin{array}{l}\text { Platinum group elements by inductively coupled plasma-mass spectrometry } \\
\text { (ICP-MS) after NiS fire assay chemical separation. }\end{array}$ & NiS fire assay \\
\hline GV & $\begin{array}{l}\text { Density, moisture and weight by gravimetry; loss on ignition (LOI) by weight } \\
\text { loss after heating at } 900^{\circ} \mathrm{C} \text {. }\end{array}$ & None \\
\hline ISE_Fuse & Fluoride by ion specific electrode after fusion digestion. & $\mathrm{LiBO}_{2}$ fusion \\
\hline ISE_HF & Chloride by ion specific electrode after multi-acid digestion with HF. & $\mathrm{KMnO}_{4}-\mathrm{H}_{2} \mathrm{SO}_{4}-\mathrm{HF}$ \\
\hline MS_ST_REE & $\begin{array}{l}\text { Rare earth elements by inductively coupled plasma-mass spectrometry (ICP-MS) } \\
\text { after } \mathrm{Na}_{2} \mathrm{O}_{2} \text { sinter digestion. }\end{array}$ & $\mathrm{Na}_{2} \mathrm{O}_{2}$ sinter \\
\hline NA_LC & $\begin{array}{l}\text { Major and minor elements by long count instrumental neutron activation analysis } \\
\text { (INAA). }\end{array}$ & None \\
\hline NA_SC & $\begin{array}{l}\text { Major and minor elements by short count instrumental neutron activation } \\
\text { analysis (INAA). }\end{array}$ & None \\
\hline TT_Flux & $\begin{array}{l}\text { Total water and bound water by Karl Fischer coulometric titration with flux after } \\
\text { combustion. }\end{array}$ & None \\
\hline TT_HCl & $\begin{array}{l}\text { Carbon dioxide (acid soluble carbon) by coulometric titration after } \mathrm{HClO}_{4} \\
\text { digestion and extraction. }\end{array}$ & $\mathrm{HClO}_{4}$ \\
\hline TT_HF & $\begin{array}{l}\text { Ferrous oxide by colorimetric or potentiometric titration after } \mathrm{HF}-\mathrm{H}_{2} \mathrm{SO}_{4} \\
\text { digestion. }\end{array}$ & $\mathrm{HF}-\mathrm{H}_{2} \mathrm{SO}_{4}$ \\
\hline WDX_Fuse & $\begin{array}{l}\text { Major and minor elements by wavelength-dispersive X-ray fluorescence } \\
\text { spectrometry (XRF) after } \mathrm{LiBO}_{2} \text { fusion digestion. }\end{array}$ & $\mathrm{LiBO}_{2}-\mathrm{Li}_{2} \mathrm{~B}_{4} \mathrm{O}_{7}$ fusion \\
\hline
\end{tabular}

A list of chemical species and their lower limits of determination (LLD) for these analytical methods are in table 2, and documentation of these methods can be found in Arbogast (1996; http://pubs.usgs.gov/of/1996/0525/report.pdf).

\section{Quality Assurance/Quality Control}

The USGS laboratories reporting these analyses use a variety of constituent standards (for example, USGS geochemical reference rock standard STM-1, nepheline syenite) and blanks for their internal quality assurance/quality control procedures (Arbogast, 1990; Taggart, 2002). Data for these reference samples are not included in the geochemical data tables, but a description of commonly used reference materials is available from the USGS (http://minerals.cr.usgs.gov/geo_chem_stand/).

\section{National Geochemical Database Dataset}

The NGDB dataset in table 3 contains 318 records (or rows), one for each rock sample analyzed, and has 20 fields (or columns) describing sample sites and the sample material collected at each site. Each sample has a unique laboratory identification number $\left(L A B_{-} I D\right)$ as well as a unique field number (FIELD_ID) provided by the sample collector. Date of sample submission is stored in the 
DATE_SUBMITTED field. LATITUDE and LONGITUDE contain the geographic coordinates; precision is set at 0.0005 degree or less depending on the level of confidence. For instance, field measurements taken with a handheld global positioning system (GPS) or from field locations plotted on USGS topographic maps have a higher level of positional certainty than those drill hole or mine/prospect locations gathered from old records with locations estimated by quarter section (given at two significant figures). The locational information is based on the North American Datum of 1927 (NAD 27) and the Clarke 1866 ellipsoid. PRIMARY_CLASS defines the sample material; SECONDARY_CLASS and SPECIFIC_NAME provide more detail about the sample medium. Other fields contain information regarding sample source, geologic age, stratigraphic and lithologic unit, mineralization, alteration, and igneous structure.

The chemical data of the NGDB dataset are contained in 194 fields or parameters. The parameter name (column header) is an abbreviation, which is a concatenation of species determined (expressed units of measurement) and analytical method used. For example, the parameter "Sb_ppm_AES_AZ_P" represents the concentration of antimony, expressed in parts per million, as detected by inductively coupled plasma-atomic emission spectroscopy after partial digestion with $\mathrm{H}_{2} \mathrm{O}_{2}-\mathrm{HCl}$ leach and diisobutyl ketone (DIBK) extract. Table 4 contains the descriptions of these parameters. Measurements are numeric values of concentration, and negative values represent the lower limit of determination for the method (for example, "less than" values, such as $<2$ ), and values ending with 0.11111 denote the upper limit of determination for the method (for example, "greater than" values, such as $>100$ are expressed as 100.11111).

\section{Summary of Geochemistry and Lithology Dataset}

The summary dataset for lithology and "best value" for geochemical data are given in table 5, which contains 318 records (or rows), one for each rock sample analyzed, and has four fields (or columns) describing the rock type and suite, and the ore deposit name and zone at each sample site. Each sample has a unique field number (FIELD_ID) provided by the sample collector, a unique laboratory number $\left(L A B \_I D\right)$ assigned to each submitted sample by the analytical laboratory that received the sample. Columns LATITUDE and LONGITUDE contain the geographic coordinates; precision is set at 0.0005 degree, based on the North American Datum of 1927 (NAD 27) and the Clarke 1866 ellipsoid. Field ROCK_DESC provides a brief description of the rock sampled as well as the mine or prospect from which the sample was taken (if appropriate). Each sample is classified into broad rock suites (ROCK_SUITE) similar to those described by Kisvarsayni (1981), the ore deposit or prospect and principal commodity of the deposit from which the sample was taken if appropriate (ORE_DEPOSIT_NAME), and the zone within the ore deposit or prospect sampled or if the sample was from the host rock (ORE_DEPOSIT_ZONE).

The chemical data of the summary dataset (table 5) is "best value" data that were populated element by element with chemical determinations and corresponding analytical method data from the NGDB by the use of Microsoft Access select and update queries. This process is detailed in Granitto and others (2013). Even when evaluating the same element, different analytical techniques will have results of varying data quality in terms of precision and accuracy, which can affect how the data can be used. Many factors including - (1) the weight of sample analyzed, (2) method of decomposition of the sample during the preparation for analysis, (3) sensitivity and accuracy of the instrument used in each method, (4) upper and lower limits of detection for a given element by a given method, (5) the age of the method and stage of its development when a specific analysis was performed, and (6) the exact analytical laboratory and equipment used - will affect the data quality and must be considered when determining which data to use for a given element. 
Creation of the summary "best value" dataset (table 4) followed a rubric or decision tree that considered all these factors in ranking the analytical methods employed in this study to determine methods most useful to mineral resource evaluation. Though an analytical method may determine multiple species concentrations, each species in the summary table was ranked individually to consider the many factors mentioned above. Table 5 contains the ranking for each species measured.

\section{Geologic Field Notes}

The geologic field notes presented in tables 6 and 7 are keyed to unique location identifiers (FIELD_ID). Table 6 provides the observations made by W.C. Day while developing the underground geologic map for the Pea Ridge mine (Seeger and others, 2001). The geochemical data in tables 3 and 5, coupled with geologic observations presented in table 6 and those unpublished by the other authors, formed the basis of the map units used in Seeger and others (2001). In table 5, the mine level (given in feet below the original ground surface) and the drift from which the observation was made is listed in column MINE_LEVEL_DRIFT. Column ROCK_TYPE lists the rock type encountered whereas column ROCK_DESC provides a more detailed description of the rock type present. Table 7 provides the sample location and geologic observations from surface outcrops, mine, and prospect waste dumps. The data field labels are identical for those used in tables 5 and 6. 


\section{References Cited}

Arbogast, B.F., 1990, Quality assurance manual for the Branch of Geochemistry, U.S. Geological Survey: U.S. Geological Survey Open-File Report 90-668, 184 p., accessed September 17, 2013, at http://pubs.usgs.gov/of/1990/0668/report.pdf.

Arbogast, B.F., ed., 1996, Analytical methods manual for the Mineral Resource Surveys Program, U.S. Geological Survey: U.S. Geological Survey Open-File Report 96-525, 248 p., accessed September 17, 2013, at http://pubs.usgs.gov/of/1996/0525/report.pdf.

Cordell, Lindrith, Sidder, G.B., and Day, W.C., 1993, Aeromagnetic constraints on shape of parent magma source at Pea Ridge, Missouri, magnetite mine: Symposium, Olympic Dam-type Deposits in the Midcontinent — Research and Exploration [abs]: Geological Society of America Abstracts with Programs, v. 25, no. 3, p. 14.

Day, W.C., Kisvarsanyi, E.B., Nuelle, L.M., Marikos, M.A., and Seeger, C.M., 1989, New data on the origin of the Pea Ridge iron-apatite deposit, southeastern Missouri-Implications for Olympic Damtype deposits [abs]: Geological Society of America Abstracts with Programs, v. 21, no. 6, p. A132.

Day, W.C., Seeger, C.M., and Rye, R.O., 2001, Review of the iron oxide deposits of MissouriMagmatic end members of the iron oxide-Cu-Au-U-REE deposit family [abs]: Geological Society of America Abstracts with Programs, v. 33, no. 6, p. 4.

Day, W.C., Sidder, G.B., Rye, R.O., Nuelle, L.M., and Kisvarsanyi, E.B., 1992, The Middle Proterozoic rhyolite-hosted Pea Ridge iron and rare-earth-element deposit-a magmatic source for Olympic Damtype deposits in the midcontinent region of the U.S.A., in Brown, P.E., and Chappell, B.W., eds., Second Hutton Symposium on The Origin of Granites and Related Rocks, Transactions of the Royal Society of Edinburgh, Earth Sciences, v. 83, Part 2, p. 489.

Day, W.C., Sidder, G.B., and Kisvarsanyi, E.B., 1993, Petrogenetic controls on the formation of middle Proterozoic iron+copper+rare earth element deposits of Missouri: Symposium, Olympic Dam-type Deposits in the Midcontinent-Research and Exploration [abs]: Geological Society of America Meeting Abstracts with Programs, v. 25, no. 3, p. 16.

Day, W.C., Sidder, G.B., McCafferty, A.E., Cordell, L.E., Kisvarsanyi, E.B., Rye, R.O., and Nuelle, L.M., 1991, A multidisciplinary study on the origin of Middle Proterozoic iron-rare earth element \pm copper \pm gold deposits in the Midcontinent region, U.S.A.: Seventh Annual V. E. McKelvey Forum on Mineral and Energy Resources, U.S. Geological Survey Circular 1062, p. 16.

Granitto, Matthew, Schmidt, J.M., Shew, N.B., Gamble, B.M., and Labay, K.A., 2013, Alaska Geochemical Database, Version 2.0 (AGDB2) - Including "best value" data compilations for rock, sediment, soil, mineral, and concentrate sample media: U.S. Geological Survey Data Series 759, 20 p. 1, DVD, accessed September 17, 2013, at http://pubs.usgs.gov/ds/759.

Groves, D.I., Bierlein, F.P., Meinert, L.D., and Hitzman, M.W., 2010, Iron oxide copper-gold (IOGC) deposits through earth history-Implications for origin, lithospheric setting, and distinction from other epigenetic iron oxide deposits: Economic Geology, v. 105, p. 641-654.

Hitzman, H.D., 2000, Iron oxide Cu-Au deposits-What, where, when, and why?, in Porter, T.M., ed., Hydrothermal Iron Oxide Copper-Gold and Related Deposits: A Global Perspective, Volume 1: Adelaide, Australian Mineral Foundation, p. 201-218.

Kisvarsanyi, E.B., 1981, Geology of the Precambrian St. Francois Terrane southeastern Missouri. Rolla, Missouri: Missouri Department of Natural Resources, Division of Geology and Land Survey Contribution to Precambrian Geology No. 8, Report of Investigations 64. 
Nuelle, L.M., Marikos, M.A., Seeger, C.M., and Day, W.C., 1989a, Hydrothermal aspects of amphibole and magnetite emplacement in the Pea Ridge Fe-REE deposit, Washington County, Missouri [abs]: Geological Society of America Abstracts with Programs, v. 21, no. 6, p. A248.

Nuelle, L.M., Seeger, C.M., Marikos, M.A., and Day, W.C., 1989b, Mineral assemblages of the Pea Ridge Fe-REE deposit-Implications of an Olympic Dam-type variant in southeast Missouri [abs]: Geological Society of America Abstracts with Programs, v. 21, no. 6, p. A34.

Nuelle, L., Day, W.D., Sidder, G.B., and Seeger, C., 1991a, Rare earth element- and gold-bearing breccia pipes of the Pea Ridge iron mine, Washington County, Missouri: American Institute of Mining Engineers Preprint number 91-109, 14 p.

Nuelle, L.M., Kisvarsanyi, E.B., Seeger, C.M., Day, W.C., and Sidder, G.B., 1991b, Structural setting and control of the Pea Ridge magnetite deposit, Middle Proterozoic St. Francois terrane, Missouri [abs]: Geological Society of America Abstracts with Programs, v. 23, no. 5, p. A292.

Nuelle, L., Seeger, C., Day, W.C., and Sidder, G.B., 1991c, Rare earth element- and gold-bearing breccia pipes of the Pea Ridge iron mine, Washington County, Missouri [abs]: Society of Metallurgy and Mining Exploration Abstracts with Programs, p. 64.

Nuelle, L.M., Day, W.C., Sidder, G.B., and Seeger, C.M., 1992, Geology and paragenesis of the Pea Ridge iron ore mine, Washington County, Missouri-Origin of the rare-earth-element- and gold-bearing breccia pipes, in Day, W.C., and Lane, D.E., eds., Strategic and Critical Minerals in the Midcontinent region, United States: U.S. Geological Survey Bulletin 1989, Chapter A, p A1-A11.

Richards, J.P., and Mumin A.H., 2013, Magmatic-hydrothermal processes within an evolving Earth-Iron oxide copper-gold and porphyry $\mathrm{Cu} \pm \mathrm{Mo} \pm \mathrm{Au}$ deposits: Geology, v. 41, no. 7, p. 767-770.

Seeger, C.M., Nuelle, L.M., Day, W.C., Sidder, G.B., Marikos, M.A., and Smith, D.C., 2001, Geologic Maps and Cross Sections of Mine Levels at the Pea Ridge Iron Mine, Washington County, Missouri: U.S. Geological Survey Miscellaneous Field Map Series MF-2353, 5 sheets, 6 p.

Sidder, G.B., and Day, W.C., 1993, Fe-Cu-REE deposits in Middle Proterozoic Rocks of the Midcontinent region of the United States: The Gangue, Geological Association of Canada Mineral Deposits Division Newsletter, Issue 42, p. 1-5.

Sidder, G.B., Day, W.C., Nuelle, L.M., Seeger, C.M., and Kisvarsanyi, E.B., 1993a, Mineralogic and fluid inclusion studies of the Pea Ridge iron-rare-earth element deposit, southeast Missouri, in Scott, R.W., Detra, P.S., and Berger, B.R., eds., Advances Related to United States and International Mineral Resources-Developing Frameworks and Exploration Technologies: U.S. Geological Survey Bulletin 2039, chap. U, p. 205-216.

Sidder, G.B., Day, W.C., and Rye, R.O., 1993b, Fluid-inclusion and stable-isotope data for the Pea Ridge Fe-REE orebody, Missouri: Symposium, Olympic Dam-type Deposits in the Midcontinent—Research and Exploration [abs]: Geological Society of America Meeting Abstracts with Programs, v. 25, no.3, p. 81.

Sidder, G.B., Nuelle, L.M., Day, W.C., Rye, R.O., Seeger, C.M., and Kisvarsanyi, E.B., 1991, Paragenesis and conditions of formation of the Pea Ridge iron and rare-earth element deposit, Missouri: Annual Meeting of the Geological Society of America [abs]: Abstracts with Programs, v. 23, no. 5, p. A292.

Taggart, J.E., Jr., 2002, Analytical methods for chemical analysis of geologic and other materials, U.S. Geological Survey: U.S. Geological Survey Open-File Report 02-0223, v. 5.0, accessed September 17, 2013, at http://pubs.usgs.gov/of/2002/ofr-02-0223/.

Williams, P.J., Barton, M.D., Fontboté, L., de Haller, A., Johnson, D.A., Mark, G., Marschik, R., and Oliver, N.H.S., 2005, Iron-oxide-copper-gold deposits-Geology, space-time distribution, and possible modes of origin: Economic Geology 100th Anniversary Volume, p. 371-406. 